УДК 785.083.1

М. Ілечко

\title{
ТЕОРЕТИЧНІ ПЕРЕДУМОВИ ВИВЧЕННЯ ФЕНОМЕНА СЮЇТНОСТІ У МУЗИЦІ
}

У статті актуалізується проблема вивчення феномена сюїтності у музиці. Визначаються основні теоретичні концепції жанру інструментальної сюїти, типи циклічних утворень як провідних факторів виникнення даного жанру.

Ключові слова: сюїта, сюїтне мислення, сюїтний цикл, музична кульmypa.

Проблема висвітлення науково-методологічних, теоретичних підходів до аналізу музичної творчості за своїм змістом є багаторівневою. Останнім часом у вітчизняному музикознавстві значно посилилась культурологічна орієнтація щодо тлумачення художніх явищ. Більшість наукових досліджень грунтуються на ідеях О. Шпенглера, I. Хейзінги, М. Бахтіна, Ю. Лотмана та інших культурологів. Це пояснюється не тільки вивільненням гуманітарних наук у пострадянську добу від моноідеологічного диктату, а й загальними потребами самої науки про музику. Все більше дослідників усвідомлюють, що неможливо зрозуміти явише, знаходячись «всередині» його. Тому монологічний підхід та метод все більше поєднуються у сучасному українському музикознавстві з діалогічним. Цілком переконливими для нашої роботи постають такі методологічні пошуки, що спираються на культурологічні концепції, інтегруючись із суміжними сферами гуманітарного знання.

Перш ніж розглянути теоретичні передумови вивчення феномену сюїтності та культурологічні аспекти проблеми сюїтності в музиці, зупинимося на визначенні самого поняття «культура», що у широкому розумінні тлумачиться багатьма вченими як процес і наслідок людської діяльності [4]. Феномен культури розуміють як творчість людей, як сукупність матеріальних і духовних цінностей, вироблених у процесі історичного розвитку. Підкреслимо, що в самій людській діяльності культура входить у конструктивно-творчі здібності, які формуються історично. 3 іншого боку, виявляється у світі певних культурних цінностей, що визначені. У зв'язку з цим є сенс говорити про актуальність визначення культури як сукупності об'єктивних цінностей, що здійснені у суспільно-історичному житті [16, с. 89].

(C) Ілечко М., 2014 
Художня культура суспільства є однією із спеціалізованих сфер, яка вирішує завдання інтелектуально-чуттєвого, духовного відображення буття. Музична культура, з цього погляду, постає як «... частина художньої культури даного суспільства у певний культурно-історичний момент його розвитку... являє собою спільність цінностей музичного мистецтва, накопичених цим суспільством, також діяльність людства і відповідних установ з виробництва, зберігання, розподілу та споживання цих цінностей». 3 таких позицій музична культура розуміється як мистецтво музики з його найближчим соціальним контекстом, з усією сукупністю суспільних «форм музикування» (Б. Асаф'єв). Музична культура є цілісним механізмом, що складається із функціонально відмінних розділів, тобто «блоків»: творчості, виконавства, розповсюдження музики, іiі сприйняття, музичної критики й музичної науки, керівництва музичною культурою. Єдність цього механізму забезпечується функціональними взаємозв'язками його складових частин, спільністю соціального базису, спільністю їх предметної основи, яку формують музичні цінності, що складають дану культуру.

Відзначимо, культурологічний та теоретичний аспект дослідження сюїтності в музиці актуалізує проблему ціннісного значення творів мистецтва. Ціннісний аналіз дозволяє визначити реальне місце художнього феномену в національному та світовому художньому процесі. Відомо, що значний практичний досвід оцінювання вже створених і функціонуючих творів мистецтва містить чимало суперечливого. Це зумовлено як незрозумілістю, нерозробленістю багатьох проблем, пов'язаних з художніми оцінками в цілому, так і складністю предмету оцінювання - інструментальної творчості вітчизняних авторів.

Музикознавча та культурологічна література вітчизняних, зарубіжних та російських авторів, предметом якої є сюїтність у музиці, залишила значну кількість матеріалів наукового, критико-публіцистичного, оглядового характеру.

Історичний ракурс дослідження сюїти достатньо широко представлений у вітчизняних та в зарубіжних виданнях. До ії передісторії звертаються В. Рабей, А. Петраш, І. Ямпольський, Ф. Блюме, А. Мілнер. У нарисі Т. Норлінда представлена еволюція лютневої сюїти у Франції, Італії та Німеччині від початку XVI до середини XVIII століття. Велику увагу автор приділяє процесу становлення основного танцювального каркасу сюїти. Г. Альтман в статті «Танцювальні форми та сюїта» пише про походження сюїти від народної селянської му- 
зики. Т. Баранова, аналізуючи танцювальну музику епохи Відродження, має на увазі, що «...окрім балу з його традиційною послідовністю танців, прообразом інструментальної сюїти могли слугувати балет і маскарадне шестя» [2, с. 9]. Композиційно-тематичні особливості сюїт англійських вьорджиналістів розглядає Т. Оганова в дисертаційному дослідженні (Т. Оганова «Англійська вьорджинальна музика: проблеми формування інструментального мислення»).

Сюїтне циклоутворення бароко висвітлюється в працях Т. Ліванової, М. Друскіна, К. Розеншильда. В монографії «Музична форма як процес» Б. Асаф'єв пропонує порівняльний аналіз Французьких, Англійських та оркестрових сюїт Й. С. Баха з метою показати різноманітні прояви контрасту як основоположного стрижня сюїтної композиції. Із зарубіжних видань з історії німецької сюїти слід виділити дослідження К. Нефа та Г. Рімана. Г. Бек виходить за рамки однієї національної - історичної різновидності, пропонуючи панораму розвитку барокової сюїти у великих європейських країнах. При цьому автор виявляє специфічні особливості жанру в різних регіонах. Він не тільки детально досліджує витоки формування сюїти, але й робить короткий перегляд європейської сюїти XIX та XX століть. Аналіз старовинної і нової романтичної сюїти представлений у працях Л. Мазеля, В. Бобровського, Т. Попової. Питання теорії та історії жанру висвітлені також в енциклопедичних статтях І. Манукян, Ю. Неклюдова, Д. Фюллера.

В історичному огляді персоналій великої уваги заслуговують праці з історії музики, історії фортепіанного мистецтва, гармонії, епістолярний матеріал та монографічні видання, серед яких виділяються монографії Д. Житомирського «Роберт Шуман», О. Левашової «М. І. Глінка», В. Брянцевої «С. В. Рахманінов». Якщо аналітикограматична форма сюїти демонструє явно виражену циклічну децентралізацію, то ії внутрішня, інтонаційна форма містить в собі деяку цілісність, що закрита за зовнішньою калейдоскопічністю. Сюїта має свою «протодраматургію», яка створює стійкий семантичний каркас, притаманний конкретно-історичним різновидам жанру, не досить схожим один на одного (буде це бахівська сюїта, нова романтична сюїта чи сюїта С. Рахманінова та Д. Шостаковича). Перелік музикознавчих праць показує, що інтерес до даної теми завжди привертав увагу дослідників [9, с. 5].

Одним з перших науковців, що дослідив проблему сюїтного циклоутворення був Б. Яворський. В «Сюїтах Баха для клавіру» та (як 
прояснилося завдяки дослідженням В. Носіної), в рукописах Б. Яворський фіксує цікавий фактологічний матеріал, що стосується як онто-, так і філогенезу барокової сюїти. Через тонкі характеристики семантичних амплуа частин він дає можливість вийти до концепційної цілісності сюїти, що дозволяє розглядати ії драматургічну модель в більш широкому історико-культурологічному контексті.

Наступний етап розвитку теорії жанру представлений дослідженнями Т. Ліванової. Вона пропонує першу у вітчизняному музикознавстві теорію циклічних форм. Т. Ліванова акцентує історичний аспект оцінки сюїтного циклоформування [8]. Але спроба розкрити драматургічний інваріант сюїти призводить до контексту «симфонієцентризму». В результаті автор констатує історичну роль сюїти всього тільки як предтечі сонатно-симфонічного циклу, тим самим невільно закриваючи власну якість сюїтного мислення.

Інтерес до сюїти як самодостатньої системи став можливим тільки тоді, коли в музикознавстві розпочали користуватися культурологічним методом дослідження. Одним із помітних явищ такого роду стала стаття М. Старчеус «Нове життя жанрової традиції», в якій по-новому висвітлюється проблематика жанру. Повертаючи нас до поетики епохи бароко, автор помічає в структурі сюїти принцип анфіладності, а також концентрує увагу на нарративній природі жанру. Розвиваючи думку М. Бахтіна про «пам'ять жанру», М. Старчеус підкреслює, що у сприйнятті сюїти важливий не стільки жанровий ансамбль, скільки авторська модальність (відношення до конкретних жанрових знаків). В результаті сюїта - як визначений тип культурної цілісності - починає наповнюватися деяким живим змістом, специфічним, притаманним тільки їй смислом. Однак цей смисл в статті виражений «ієрогліфічно» [14, с. 52].

Логіка внутрішнього процесу сюїти залишається загадкою, як залишається поза увагою деякий внутрішній механізм саморуху циклу, драматургічний «сценарій» сюїтного ряду. Значну роль у спробі розшифрування іманентного логосу сюїтності в музиці відіграла розробка функціонального підходу до музичної форми. Провідним принципом циклічних форм дослідник В. Бобровський вважає зв'язок частин на основі драматургічних функцій. Саме у функціональному зв'язку частин полягає основна відмінність сюїти від сонатно-симфонічного циклу. Так, науковець В. Цукерман бачить в сюїті прояв єдності у множинності, а в сонатно-симфонічному циклі - множинність єдності. За спостереженням іншого вченого 
О. Соколова, якщо в сонатно-симфонічному циклі діє принцип субординації частин, то сюїта відповідає принципу координації частин. В. Боровський виділяє аналогічну функціональну відмінність між ними: «Сюїта - об'єднання ряду контрастуючих творів, сонатно-симфонічний цикл, навпаки, розділення єдиного твору на ряд підкорених цілому окремих творів» [5]. М. Арановський також спостерігає полярні тенденції в інтерпретації розглядуваних багаточастинних циклів: підкреслену дискретність в сюїті та внутрішньо подолану дискретність при збереженні її зовнішніх ознак - в симфонії [1, с. 7].

Н. Пікалова, автор дисертаційного дослідження з теорії сюїти, виходить на дуже важливу проблему інтеграції частин в єдиний музичний організм. «Сюїтний цикл достатньо відрізняється від сонатно-симфонічного, однак не відсутністю чи недостатністю єдності, а скоріш за все, іншими принципами єдності» [12]. Сам же фактор єдності дійсний для сюїти, бо поза ним множинність сприймалась як хаос, а не як естетично обумовлена багатоманітність». Н. Пікалова визначає сюїту як «...складний жанр, в основі якого лежить вільна багатокомпонентна циклічність, виражена через контрастування частин (моделей простих жанрів), скоординованих узагальненою художньою ідеєю та в сукупності направлених на втілення естетичної цінності багатоманітності явищ дійсності».

В сфері трактування послідовності мініатюр як єдиного музичного організму стала стаття В. Бобровського «Аналіз композиції «Картинок з виставки» М. Мусоргського», видана в 1976 році. Помітивши принцип наскрізного розвитку в ладово-інтонаційній сфері, автор виходить на проблему композиційної єдності циклу. Подальший розвиток ця ідея отримує в працях А. Меркулова про сюїтні цикли Р. Шумана та «Картинок з виставки» М. Мусоргського, а також стаття О. Ручьєвської та Н. Кузьміної «Поема «Отчалившая Русь» в контексті авторського стилю Г. Свиридова». В кантаті Г. Свиридова «Нічні хмари» Т. Масловська спостерігає складну, «контрастну» близькість частин, багатопланові зв'язки між ними. Тенденції до сприйняття сюїтної цілісності на рівні ладово-інтонаційної та композиційної єдності відкривають нові горизонти дослідження, надаючи можливість торкнутися його семантико-драматургічного аспекту [10, с. 78]. В цьому ключі розглядає «Дитячий альбом» П. Чайковського А. Кандинський-Рибников, спираючись на дійсний, на його думку, прихований в рукописному варіанті твору авторський підтекст. 
Взагалі, сучасна література про сюїту відзначається цілком різноманітним підходом до питання змісту і композиційної єдності сюїтного циклу. Н. Пікалова бачить смисловий стрижень сюїти в ідеї контрастної множинності, а іiі художній образ - в об'єднаній множинності даностей. В результаті сюїта являє собою «множинний ряд самоцінних даностей». В. Носіна, розвиваючи ідеї А. Швейцара, Б. Яворського, М. Друскіна про співставлення типів руху в сюїті, вважає, що головним змістом сюїт є аналіз руху: «Невипадково розквіт жанру сюїти співпав в часі з епохою розробки класичних методів опису руху у фізиці та математиці» [11]. Жанр сюїти, на думку автора, дає «...спосіб музичного осягнення ідеї руху». Дослідниця О. Щелкановцева прослідковує аналогію між шестичастинним циклічним каркасом Сюїт для віолончелі соло Й. С. Баха та ораторською мовою, що має чітке розмежування на шість частин [17]:

Exordium (вступ) - Прелюдія.

Narratio (оповідання) - Алеманда.

Propositio (мова) - Куранта.

Confutatio (заперечення) - Сарабанда.

Confirmatio (ствердження) - вставні танці.

Peroratio (заключення) - Жига.

За замітками вченого В. Рожновського, даний квадривіум функцій та основні розділи побудови мови відображають всезагальні закони діалектики і, відповідно, створюють концептуальну основу сонатно-симфонічної драматургії, але не сюїтної. На думку дисертантки С. Маслій, інтерпретація О. Щелкановцевої для самих частин сюїти також цілком проблематична та викликає деякі сумніви. Так, розділ Confutatio (заперечення) скоріше за все відповідає не сарабанді, а вставним танцям, які створюють різкий контраст не тільки по відношенню до сарабанди, але і до основного танцювального каркасу в цілому. В свою чергу, жига, що є заключною частиною, функціонально більш близька як до розділу Peroratio (заключення), так і до Confirmatio (ствердження).

При всій своїй зовнішній дискретності, розчленованості сюїта володіє і драматургічною цілісністю. Як єдиний художній організм, вона, за твердженням Н. Пікалової, розрахована «...на сукупне сприйняття частин у визначеній послідовності... В рамках сюїти тільки весь цикл - являє собою закінчену цілісність». Поняття драматургічної цілісності - прерогатива внутрішньої форми сюїти. Вчена I. Барсова наголошує: «Знайти внутрішню форму - значить виділити серед 
даного дещо таке, в чому полягає імпульс подальшого перетворення» [3, с. 112]. Досліджуючи внутрішню структуру музичного жанру, М. Арановський вважає, що вона обумовлює іманентність жанру та забезпечує його стійкість у часі: «Внутрішня структура вміщує «генетичний код» жанру, і виконання закладених в ній умов забезпечує відтворення жанру в новому тексті» [1, с. 38].

Проблеми сюїтної циклізації неодноразово торкалися й українські музикознавці. Фундаментальна праця В. Клина «Українська радянська фортепіанна музика» [7] відобразила новий в українському музикознавстві напрямок у методах комплексного вивчення камерно-інструментальних жанрів. У просторі дослідження еволюції фортепіанної творчості українських композиторів XX століття В. Клин здійснив класифікацію та систематизацію ії жанрового фонду та визначив тематичний спектр ії образності.

У дисертації М. Калашник «Інтерпретація жанрів сюїти й партити у творчій практиці ХХ століття» (1991) вперше здійснено аксіологічний підхід до жанрів сюїти й партити, зроблена диференціація їх жанрових властивостей як відносно самостійних історико-культурних одиниць, сформульовані дефініції сюїти і партити, виявлені і зведені у схеми основні їх модуси [6].

Дослідниця I. Тукова, навпаки, не диференціює жанрові ознаки сюїти і партити [15]. В якості головних ознак старовинної танцювальної сюїти і партити дослідниця виділяе структуру (багаточастинний твір, ланки якого співвідносяться за принципом контрасту); засоби жанрової специфікації (обумовлені специфікою закріплених за частинами танцювальних і нетанцювальних номерів); широкий діапазон складу виконавців (від солюючого інструменту до оркестру) [15, с. 12].

У процесі дослідження фортепіанних сюїт, партит і сонат львівських композиторів XX століття (М. Колесси, В. Барвінського, А. Рудницького, Р. Сімовича, М. Скорика, Б. Фільц) С. Салдан також акцентує суперечливість співвідношень між вказаними жанрами. «Усі вони $є$ циклами, але їх жанрова характеристика може мати варіантні тлумачення: соната може наближатися до сюїти, сюїта набувати рис сонатного циклу і таке інше» [13, с. 9]. Зауважуючи, що вищезгадані цикли базуються на принципі контрасту, дослідниця наголошує, що контраст у сюїтах і партитах слугує для роз'єднання, а у сонатах - для об'єднання, адже у сонатному циклі «відбувається заміна відносно самодостатніх одиниць на підрядні, тобто такі, що обов'язково знаходяться у певних взаємозв'язках» [13, с. 10]. Таким 
чином, як і більшість дослідників, С. Салдан приходить до висновку, що «сюїтні і партитні цикли складаються з послідовності різних відносно самодостатніх одиниць, а у сонатних циклах, завдяки вказаній супідрядності, утворюється диференційована цілісність драматургічного плану» [13, с.10].

Отже, підсумовуючи вищесказане, можна зробити висновок, що наукове знання про сюїту як жанр є великим та багатомірним. На сучасному етапі розвитку музикознавства розмежовуються зовнішні та внутрішні форми (визначення I. Барсової), аналітико-граматичні та інтонаційні форми (визначення В. Медушевського). Як аналітикограматична форма, в якості особливого виду циклоформування, сюїта отримала опис у дослідженнях Б. Асаф'єва, В. Бобровського, В. Яворського, в працях з аналізу музичних форм Л. Мазеля, С. Скребкова, I. Способіна, В. Цуккермана. Звернення до жанру сюїти обумовлено підвищеним інтересом до нього у європейському мистецтві та мистецтвознавстві останніх двох століть і водночас недостатньою його науковою дослідженістю. Зокрема, досі не з'ясована художньо-культурна цінність сюїти у фортепіанній музиці українських композиторів останньої третини XX століття та не створено внутрішньожанрову типологію сюїти. До цього часу немає чіткого актуалізованого наукового визначення поняття «сюїтного мислення» у його онтологічному значенні, але це вже проблема нашого подальшого дослідження.

\section{СПИСОК ЛІТЕРАТУРИ}

1. Арановский М. Структура музыкального жанра и современная ситуация в музыке / М. Арановский // Муз. современник. - М. : Сов. композитор, 1987. - Вып. 6. - С. 5-45.

2. Баранова Т. Танцевальная музыка эпохи Возрождения / Т. Баранова // Музыка и хореография современного балета : сб. ст. - М., 1982. - Вып. 4. C. $8-35$.

3. Барсова И. Специфика языка музыки в создании художественной картины мира / И. Барсова // Художественное творчество. Вопросы комплексного изучения. - М., 1986. - С. 99-116.

4. Бердяев Н. Смысл истории / Н. Бердяев. - М. : Мысль, 1990. - 176 с.

5. Бобровский В. П. Функциональные основы музыкальной формы / В. П. Бобровский. - М. : Музыка, 1977. - 332 с.

6. Калашник М. П. Интерпретация жанров сюиты и партиты в творческой практике XX века : автореф. дис. ... канд. искусствовед. : 17.00.02 / М. П. Калашник ; Киев. консерватория им. П. И. Чайковского. - К., 1991. - 15 с.

7. Клин В. Синтетичні жанри / В. Клин // Українська радянська фортепіанна музика. - К. : Наук. думка, 1980. - С. 234-304. 
8. Ливанова Т. Музыкальная драматургия Й. С. Баха и ее исторические связи / Т. Ливанова. - М. ; Л. : Музгиз, 1948. - (Ч. 1 : Симфонизм). - 231 с.

9. Маслий С. Ю. Сюита: семантико-драматургический и исторический аспекты исследования : дис. ... канд. иск. / С. Ю. Маслий. - М., 2003. $170 \mathrm{c}$.

10. Масловская Т. «Жизни строй и вечности огни...» / Т. Масловская // Музыкальный мир Георгия Свиридова : [сб. статей]. - М., 1990. - С. 78-92.

11. Носина В. О символике «Французских сюит» И. С. Баха / В. Носина // Б. Яворский. Сюиты Баха для клавира. - М. : Классика-XXI, 2006. C. $67-151$.

12. Пикалова Н. Б. Камерная инструментальная сюита в русской советской музыке 60-х - первой половины 80-х годов: (Теорет. аспекты жанра) : автореф. дис. ... канд. искусствовед. : спец. 17.00.02 / Н. Б. Пикалова; Ленинград. гос. ин-т театра, музыки и кинематографии им. Н. К. Черкасова. - Ленинград, 1989. $-24 \mathrm{c}$.

13. Салдан С. О. Жанрово-стильові моделі у фортепіанній творчості львівських композиторів XX століття : автореф. дис. ... канд. мистецтвознавства : спец. 17.00.03 / С. О. Салдан; Нац. муз. акад. України ім. П. І. Чайковського. - K., 2006. - 17 c.

14. Старчеус М. Новая жизнь жанровой традиции / М. Старчеус // Музыкальный современник. - М. : Сов. композитор, 1987. - Вып. 6. - С. 45-68.

15. Тукова I. Функціонування інструментальних жанрових моделей західноєвропейського бароко в українській музиці другої половини XX ст. : автореф. дис. ... канд. мистецтвознавства : спец. 17.00.03 / І. Тукова. - К., 2003. $19 \mathrm{c}$.

16. Философский энциклопедичекий словарь / [редкол. : Е. Ф. Губский, Г. В. Кораблева, В. А. Лутченко]. - М. : ИНФРА-М, 1997. - 576 с.

17. Шелкановцева Е. Сюиты для виолончели solo И. С. Баха / Е. Щелкановцева. - М. : Музыка, 1997. - 112 с.

Илечко М. Теоретические предпосылки изучения феномена сюитности в музыке. В статье актуализируется проблема изучения феномена сюитности в музыке. Определяются основные теоретические концепции жанра инструментальной сюиты, типы циклических образований как ведущих факторов возникновения данного жанра.

Ключевые слова: сюита, сюитное мышление, сюитный цикл, музыкальная культура.

Ilechko M. The theoretical preconditions to study of the phenomenon of suite in music. This article is actualities the problem to study of the phenomenon of suite in music. To definite fundamental of theoretical concepts to the genre of instrumental suite, the type of cyclical forms as the principal factors to emergence this genre.

Key words: suite, the thought of suite, the cycle of suite, the culture of music. 